UDC 330

\title{
SOME ASPECTS OF ECONOMIC-GEOGRAPHICAL VIEW ON THE SUSTAINABLE DEVELOPMENT OF WATER RESOURCES
}

\author{
Goran Rajović \\ International Network Center for Fundamental and Applied Research, Russian Federation \\ E-mail: dkgoran.rajovic@gmail.com
}

\author{
Jelisavka Bulatović \\ College of Textile Design, Technology and Management, Belgrade, Serbia \\ E-mail: jelisavka.bulatovic@gmail.com
}

\begin{abstract}
Taking care of water is the task and responsibility of each individual. It means that every person on the planet Earth, regardless of his place of life, should be given a personal contribution how to the next generation had conditions for living. All knowledge and knowledge about water, man at any moment of its existence on planet Earth, do not give any right to the unlimited consumes and contaminates. Water resources which meant life on Earth and biological diversity as we have made available, oblige us to rational treatment, not only rational, but also with due diligence master. Cares and attitude towards water should be both individual and shared. Each of us must take into account the consumption of water, the environment of which water is an important part of, and understand that polluting pollute the environment and water. Each of us can make that little step and show good will and actually cultured attitude towards water and to all who need it, but it is necessary to every living being, every community. We should not forget that we ourselves constructed of water and to taking care of water, care about yourself, their children and generations who is are coming (Vučijak et al,2011). In this paper, we point to some economic - geographical aspects of sustainable development of water resources. Sustainable water management is a critical component of sustainable development. "Sustainable water management are should contribute to the objectives of society and maintain ecological, environmental, and hydrologic integrity" (Loucks and Gladwell, 1999).
\end{abstract}

\section{KEY WORDS}

Sustainable development, water resources, aspects.

Water is the world's most critical natural resource. It is unquestionable that the survival of the human species depends fundamentally on the availability of quality water. The severe scarcity of water is a global concern for now and the future. On the demand side, rapid population growth and economic development will lead to even higher demand for water worldwide (Xi, 2012). On the supply side, by Xi (2012) citing research WCED (1987) and Piao et al (2010) emphasizes that climate change has caused the rainfall to be less predictable and natural sources of water less reliable. The demand-supply imbalance in the water sector calls for more innovative water management practices, so as to provide sufficient quality water for present and future generations. This is the ultimate goal of sustainable water resources management, in alignment with the United Nations' broader definition of sustainability.

Heintz (2010) emphasizes that sustainable development is a program of action that has emerged from peoples' basic values, from concerns about the consequences of past development, and from scientific concepts of sustainability. The most widely accepted statement of sustainable development was set forth by the Brundtland Commission in 1987: "Sustainable development is development that meets the needs of the current generation without compromising the opportunities of future generations to meet their needs" (World Commission on Environment and Development, 1987). "The term has come to encompass the economic, environmental and social realms, focusing particularly on the unintended or 
undesirable environmental and social consequences of economic development. The concept of sustainable development has focused policy, management, and design efforts on the search for ways to increase economic output while reversing the degradation of environmental resources and making the distribution of economic and environmental outcomes more equitable" (Heintz, 2010).

Water plays an important and critical role in the sustainable development of a social system. In 1996, according to Li (2009) citing research Loucks et al (1996) emphasizes that the United Nations Educational, Scientific and Cultural Organization (UNESCO) / American Society of Civil Engineers (ASCE)(2006) committee on Sustainable Water Use Strategies has defined the sustainable water resource management - fully contribute to the needs of society, now and in the indefinite future, while protecting their cultural, ecological, and hydrological integrity. However, with the development of population and production systems in recent years, the unsustainable development of water resources has become conspicuous. Especially in developing countries with limited alternative options, the water crisis has become a severe problem including water resource shortage, water pollution, deterioration of eco-systems, climate change...

\section{MATERIALS AND METHODS}

The presented material was mainly based on the study of many international specialty papers (see references at the end of the paper), from the Some aspects of sustainable development of water resources, on the occasion of documentation, as well as in consultation with numerous articles and studies published on Internet (see Chiristecu, 2011; Rajović and Bulatović, 2013-2016). A number of official websites of institutions and central and local management bodies has been taken from: World Commission on Environment and Development (1987), United Nations (1992), United Nations Educational, Scientific and Cultural Organization (UNESCO) / American Society of Civil Engineers (ASCE) (2006), World Bank (2007), FAO (2011), FAO (2013), Water Institute; Gillings School of Global Public Health; University of North Carolina (2014), IWMI (2014), (UNDESA) (2015), (MDGs) (2015), and others.

\section{ANALYSIS AND DISCUSSION}

Over $70 \%$ of our Earth's surface is covered by water. Although water resources are seemingly abundant, the real issue in respect to agriculture is the amount of fresh water available. $97.5 \%$ of all water on Earth is salt water, leaving only $2.5 \%$ as fresh water. Nearly $70 \%$ of that fresh water is frozen in the icecaps of Antarctica and Greenland; most of the remainder is present as soil moisture, or lies in deep underground aquifers as groundwater not accessible to human use. $1 \%$ of the world's fresh water $(\sim 0.007 \%$ of all water on earth) is accessible for direct human uses ( Figure 1). This is the water found in lakes, rivers, reservoirs and those underground sources that are shallow enough to be tapped at an affordable cost. Only this $1 \%$ is regularly renewed by rain and snowfall, and is therefore available (www.farm-zero.com).

The total water resources in the world are estimated in the order of $43750 \mathrm{~km}^{3} / \mathrm{year}$, distributed throughout the world according to the patchwork of climates and physiographic structures. At the continental level, America has the largest share of the world's total freshwater resources with 45 percent, followed by Asia with 28 percent, Europe with 15.5 percent and Africa with 9 percent. At a country level, there is an extreme variability in TRWR: from a minimum of $10 \mathrm{~m}^{3} /$ inhabitant in Kuwait to more than $100.000 \mathrm{~m}^{3} /$ inhabitant in Canada, Iceland, Gabon and Suriname. For 19 countries or territories, the TRWR per inhabitant are less than $500 \mathrm{~m}^{3}$; and the number of countries or territories with less than $1000 \mathrm{~m}^{3} /$ inhabitant is 29. The ten poorest countries in terms of water resources per inhabitant are Bahrain, Jordan, Kuwait, Libyan Arab Jamahiriya, Maldives, Malta, Qatar, Saudi Arabia, United Arab Emirates and Yemen. In the large countries, water resources are also distributed unevenly in relation to the population (www.fao.org). 


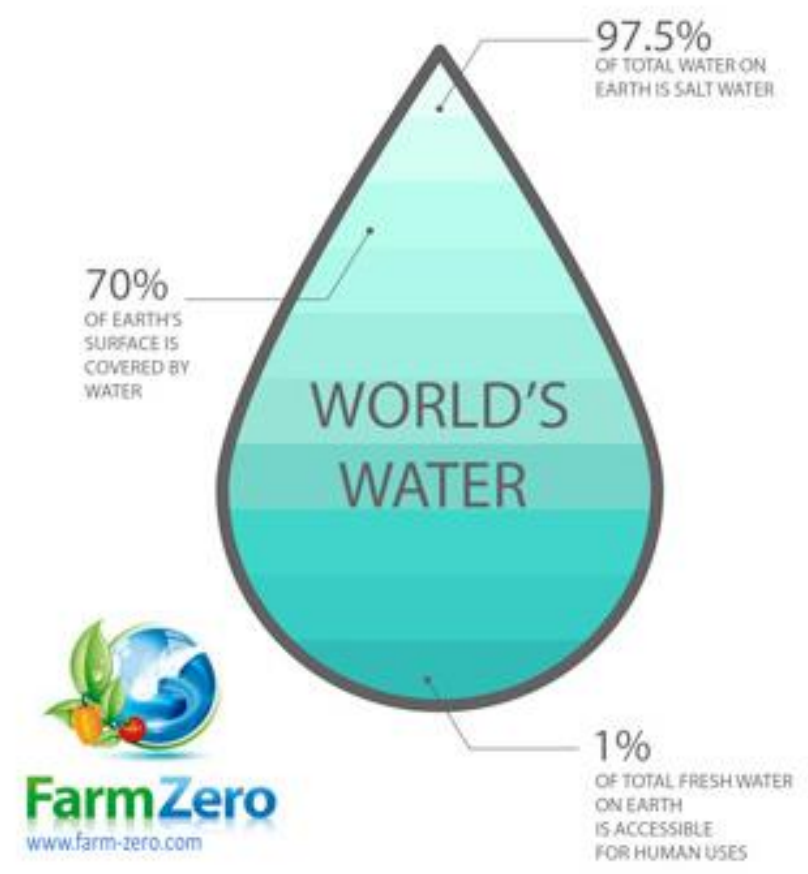

Figure 1 - Water Resources of Earth (www.farm-zero.com)

Nine countries are the world giants in terms of internal water resources, accounting for 60 percent of the world's natural freshwater (Brazil, Russian Federation, Canada, Indonesia, China, Columbia, United States of America, Perry and India). At the other extreme, the water poor countries are usually the smallest (notably islands) and arid ones (Israel, Jordan, Libyan, Mauritania, Cape Verde, Djibouti, United Arab Emirates, Qatar, Malta, Gaza Strip, Bahrain, Kuwait).In an average year, $1000 \mathrm{~m}^{3}$ of water per inhabitant can be considered as a minimum to sustain life and ensure agricultural production in countries with climates that require irrigation for agriculture. Thirty-three countries depend on other countries for over 50 percent of their renewable water resources: Argentina, Azerbaijan, Bahrain, Bangladesh, Benin, Bolivia, Botswana, Cambodia, Chad, Congo, Djibouti, Egypt, Eritrea, Gambia, Iraq, Israel, Kuwait, Latvia, Mauritania, Mozambique, Namibia, Netherlands, Niger, Pakistan, Paraguay, Portugal, Republic of Moldova, Romania, Senegal, Somalia, Sudan, Syrian Arab Republic, Turkmenistan, Ukraine, Uruguay, Uzbekistan, Viet Nam and former Yugoslavia (www.fao.org).

Having read several sustainability reports from the likes of Wall - Mart, Starbucks, Target, Weyerhaeuser, Buckeye Technologies, Domtar, Sonoco, and more, one is intrigued by how little interest was granted to water conservation. But concerns don't stop here. One learns about sustainability initiatives being the advantage that companies needed to boost sales, enhance an image, and please stakeholders. However, after reading an article that "being green isn't such a unique thing anymore" and "at the end of the day, sustainability is just one of many things big companies evaluate when choosing suppliers, and it's not usually at the top of the list". Does this mean that most companies feel they have climaxed in sustainability efforts because the attention it has gained is supposedly dying down? If that's the case, then there is a new recommendation that arches over individual organization sustainability efforts, and that is creating access to safe, clean water in less developed third world countries (Love and Luchsinger, 2014).

Currently according to Flint (2010) citing research Vorosmarty et al (2000) and Ryan (1997) points out that large proportion of the world's population is experiencing water stress. Rising population demands for water from irrigation ( $70 \%$ of all water uses), industrial $(20 \%)$, and residential (10\%) uses greatly outweigh greenhouse warming affects on world water supplies. Likewise, humans use more than $50 \%$ of the available freshwater in our world, $60 \%$ of which is wasted, leaving less than half for all other life forms on Earth. The average 
quarter-pound hamburger requires 616 gallons of water to create its meat; the cheese requires 56 gallons; and the making of the bun 25 gallons of water. The average U.S. household uses about 50 gallons per person per day, a rate more than seven times the per capita average in the rest of the world and nearly triple Europe's level. Yet the World Health Organization says good health and cleanliness require a total daily supply of about 8 gallons per person per day (see Table 1).

According to Love and Luchsinger (2014) nearly the entire Middle Eastern region experiences physical water shortages while the majority of Africa is home to economic water scarcity as well. Yemen and Jordan have the most severe water shortages in the Middle East and North Africa. Governments and policy makers in these countries are starting to realize the costs of water scarcity, which explains $20-30 \%$ of the budget being spent on water in Algeria, Egypt and Morocco. Water scarcity leads to inefficient land use, overuse of nonrenewable water resources, pollution, ecological damage, and poorly maintained infrastructure. Love and Luchsinger (2014) citing research World Bank (2007) some reports indicate water - related environmental problems to cost countries between .5 and $2.5 \%$ of their annual GDP. Three quarters of the deaths from poor health in the developing world come from water - borne disease.

Table 1 - Why Be Concerned About Our Water Resources? ${ }^{1}$

\begin{tabular}{|c|c|c|}
\hline Water Resource Availability & How Safe Is Our Water? & Water and World Security \\
\hline $\begin{array}{l}\text { Average U.S. household uses about } \\
50 \text { gal / person/day, nearly triple } \\
\text { Europe's level and more than } 7 \\
\text { times the rest of the world (ENS, } \\
1999 \text { ). } \\
\text { The World Health Organization } \\
\text { says good health and cleanliness } \\
\text { require a total daily supply of about } \\
8 \text { gal / person / day( Collier, 1999). } \\
\text { Two - thirds of residential interior } \\
\text { water is used for toilet flushing ( } 4 \\
\text { gal/flush) and bathing (15-50 } \\
\text { gal/shower or bath) while a } \\
\text { dishwasher uses } 8-12 \text { gal and a top } \\
\text { loading clothes washer } 40 \text { - } 55 \text { gal } \\
\text { (ENS, } 1999 \text { ). } \\
\text { Land irrigation pumping extracts } \\
\text { underground water much faster } \\
\text { than it is replaced and spray } \\
\text { irrigation loses } 1 / 3 \text { of water to } \\
\text { evaporation before reaching plant } \\
\text { roots (Lazaroff, } 2000 \text { ). } \\
\text { The Ogallala aquifer ( } 1 / 5 \text { of U.S. } \\
\text { irrigated land) is overdrawn by } 12\end{array}$ & $\begin{array}{l}\text { In 1996, } 263 \text { million tons of } \\
\text { Nitrogen and } 18 \text { million pounds of } \\
\text { Phosphorus ran into the } \\
\text { Chesapeake Bay (ENN, 1998). } \\
\text { Fish advisories for risks to human } \\
\text { health have become a standard } \\
\text { practice of the 1980s and 1990s } \\
\text { (ENN, 1999). } \\
\text { In } 1986 \text { a study statistically linked } \\
\text { children with leukemia in Woburn, } \\
\text { Massachusetts to contaminated } \\
\text { drinking water affected by a nearby } \\
\text { waste site (Montague, 1998). } \\
\text { Clusters of child leukemia are } \\
\text { occurring in regions where drinking } \\
\text { water has been contaminated by } \\
\text { carcinogenic volatile organic } \\
\text { compounds from industry } \\
\text { (Sutherland, 1999). } \\
\text { In 1995, } 29 \text { cities \& towns in U.S. } \\
\text { cornbelt had herbicides in drinking } \\
\text { water that exceeded federal safely } \\
\text { levels (Grossman, 1998). }\end{array}$ & $\begin{array}{l}\text { Israelis and Palestinians have } \\
\text { argued for years over how to share } \\
\text { the Mountain Aquifer beneath the } \\
\text { West Bank (Edie Summaries, } \\
2000 \text { ). } \\
\text { Pakistan and India have been in } \\
\text { conflict for centuries over water in } \\
\text { the Indus and Ganges Rivers, } \\
\text { which both originate in Kashmir } \\
\text { (Mustikhan, 1999). } \\
\text { While the Syrians press for an } \\
\text { Israeli withdrawal from the Golan } \\
\text { Heights, water, not land is the } \\
\text { crucial issue between the two } \\
\text { countries. The Golan } \\
\text { Heights provides more than 12\% of } \\
\text { Israel's water requirements (Edie } \\
\text { Summaries, 2000). } \\
\text { The Nile River in Africa runs } \\
\text { through ten countries (ENS, 1999). } \\
\text { Malaysia sells water to neighboring } \\
\text { Singapore and is now demanding } \\
\text { an increase in the price of this }\end{array}$ \\
\hline
\end{tabular}

${ }^{1}$ The following references have used Flint (2010): ENS (1999), Growing Population Faces Shrinking Water Supply, Available from: http://ens.lycos.com; Collier, C., (1999), Save Some for Tomorrow. Environment News Service, Available from: http://ens.lycos.com/ewire; Lazaroff, C., (2000), Growing population faces diminishing resources, In Environment News Service, Available from: http://ens.lycos.com; Center for New American Dream (2000), Available from: http://www.newdream.org; Brown, L., (1999), China's Water Crisis Linked to Global Security, Population Press, 5(5), 5; GreenBiz.com (2003), Humanity Wages War with Nature for Water, Environmental News Network, New York, Available from: http://www.enn.com; Wilson, A., Yost, P.,(2001), Buildings and the environment: the numbers, Environmental Building News, 1 May; ENN (Environmental News Network)(1998), Heavy Rains Drive Home Pollution Problem, Available from: http://www.enn.com; ENN (Environmental News Network)(1999), Beware, Don't Eat the Fish, Available from: http://www.enn.com; Montague, P., (1998), Landfills are Dangerous, Rachel's Environment and Health Weekly, 617, 2, Available from: http://www.rachel.org; Sutherland, D., (1999), Tug-o-War: Cancer kids vs water pollution, Environment News Service, Available from: http://ens.lycos.com Grossman, R., (1998), Can Corporations Be Held Accountable? Part I, Rachel's Environment and Health Weekly, 609. Available from: http://www.rachel.org; Barker, R. (1997), And the Waters Turned to Blood, New York: Simon and Schuster, ENS (2003), Threats Rising for U.S. Public Water Supplies, Available from: http://ens-news.com Borenstein, S., (1998), Coastal Waters have big problems, Harvard study says. The Buffalo News, 25 August; Edie Summaries (2000), Israel: Water Not Land is Key to Shepherdstown Talks, Available from: http://www.edie.net; Mustikhan, A., (1999), Pakistan Provinces Feud Over Water, In Environment News Service (ENS), 7/28/99,

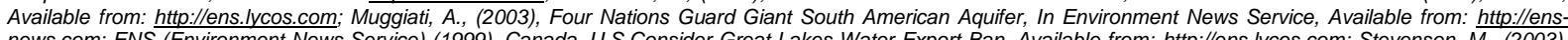

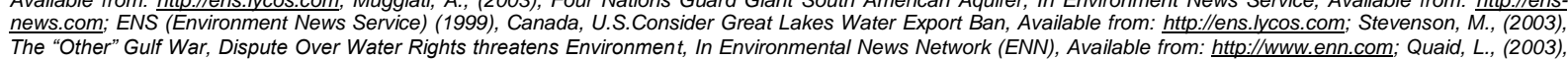
Missouri River Ruling Could Hinder Water Quality, In Environmental News Network, Available from: http://www.enn.com; IATP (Institute for Agriculture and Trade Policy) (2003), Maryland in Control of Virginia's Destiny, US Water Network Publication, 4 April. Minneapolis, MN. 


\begin{abstract}
billion cubic $\mathrm{m} / \mathrm{yr}$ causing more than two million acres of farmland to be taken out of irrigation (Center for New American Dream, 2000).
\end{abstract}

China is draining some of its rivers dry and now mining ancient aquifers that take thousands of years to recover

(Brown, 1999).

Africa's Lake Chad has shrunk from a surface area of $25,000 \mathrm{sq} \mathrm{km}$ in 1960 to only $2,000 \mathrm{sq} \mathrm{km}$ today (GreenBiz.com, 2003).

Mexico City is sinking as residents pump water beneath them elevated train tracks, built flat in the 1960s, look like roller coasters now (Center for New American Dream, 2003).

One-fifth of the world's freshwater fish -2.000 of the 10.000 species identified so far - are endangered, vulnerable, or extinct (GreenBiz.com, 2003).

Globally the world has lost half of its wetlands, mostly in the last 50 years (Wilson and Yost, 2001).

Two of every 3 persons could live in water-stressed conditions by the year 2025 (GreenBiz.com, 2003).
Between 1976-1996, annual rates of harmful algae blooms - leading indicator of health risks for marine animals and people - increased from 74 to 329 (Barker, 1997).

Aging infrastructure, source water pollution and outdated treatment technology increase human health risks in 19 US cities (ENS, 2003).

Mass fish kills and disease outbreaks went from nearly unheard of before 1973 to almost 140 events in 1996

(Borenstein, 1998).

Stranding of whales, dolphins, and porpoises linked to poor oceanic environmental conditions jumped from nearly zero in 1972 to almost 1.300 in 1994 (Borenstein, 1998).

\section{water (ENN}

2003).

The Mercosul countries of Brazil, Argentina, Uruguay, and Paraguay launched a project for preservation of the

Guarani Aquifer that serves all four countries (Muggiati, 2003).

Canada and the U.S. signed a treaty approximately 10 years ago that states no water can be removed from the Great Lakes basin (ENS, 1999).

Mexico and the U.S. have a longstanding treaty for maintaining water flow in the Colorado River ( Stevenson, 2003).

Along the Missouri River, there is conflict among navigation, power generation, and environmental concerns

(Quaid, 2003).

Maryland is in control of Virginia's water destiny (IATP, 2003).

Source: Flint (2010

Other signs are just as frightening (Table 1). In 1986, a study statistically linked children with leukemia in Woburn, Massachusetts to contaminated drinking water affected by a waste site nearby. A study released in 1995 has shown that herbicides in drinking water exceed federal safety levels in 29 cities and towns in the U.S. corn - belt. Israelis and Palestinians have argued for years over how to share the Mountain Aquifer, which lies beneath the West Bank. Pakistan and India have engaged in conflict for centuries over water rights to the Indus and Ganges Rivers ( Flint, 2010).

This is the step in a long journey to encourage a progressive economy, which continues to provide us with high living standards, but at the same time helps reduce pollution, waste mountains, other environmental degradation, and environmental rationale for future policy - making and intervention to improve market mechanisms (Omer, 2010). This vision according to Omer (2010) will be accomplished by: (1) decoupling' economic growth and environmental degradation. The basket of indicators illustrated shows the progress being made (see Table 5); (2) decoupling air and water pollution from growth, making good headway with $\mathrm{CO} 2$ emissions from energy, and transport. The environmental impact of our own individual behavior is more closely linked to consumption expenditure than the economy as a whole. Focusing policy on the most important environmental impacts associated with the use of particular resources, rather than on the total level of all resource use; (3) increasing the productivity of material and energy use that are economically efficient by encouraging patterns of supply and demand, which are more efficient in the use of natural resources. The aim is to promote innovation and competitiveness. Investment in areas like energy efficiency, water efficiency and waste minimization and (4) encouraging and enabling active and informed individual and corporate consumers. 
Eurasia: Economics \& Business, 1(1), February 2017

DOI https://doi.org/10.18551/econeurasia.2017-01

Table 2 - The basket of indicators for sustainable consumption and production

\begin{tabular}{|c|}
\hline Economy - wide decoupling indicators \\
Greenhouse gas emissions \\
Air pollution \\
Water pollution (river water quality) \\
Commercial and industrial waste arising and household waste not cycled \\
Resource use indicators \\
Material use \\
Water abstraction \\
Homes built on land not previously developed, and number of households \\
Decoupling indicators for specific sectors \\
Emissions from electricity generation \\
Motor vehicle kilometers and related emissions \\
Agricultural output, fertilizer use, methane emissions and farmland bird populations \\
Manufacturing output, energy consumption and related emissions \\
Household consumption, expenditure energy, water consumption and waste generated.
\end{tabular}

Source: Omer (2010).

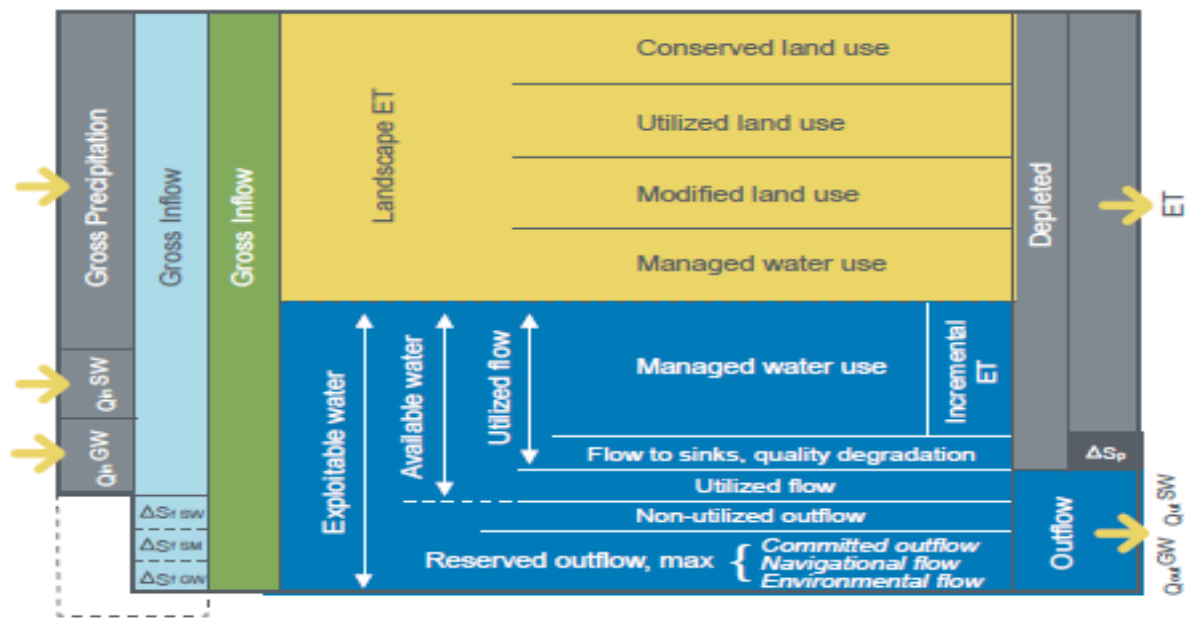

Figure 2 - Schematic presentation of the resource base sheet (Water Accounting + )

( Karimi et al, 2013)

Several organizations, including FAO (2011), United Nations Educational, Scientific and Cultural Organization - Institute for Water Education (UNESCO-IHE) (2014) and IWMI (2014) are working towards better and more effective monitoring of water. Water Accounting Plus (WA+), developed by IWMI (2014) and partners, and explores the wealth of global open access data and the development of an international standard to express complex water management issues. WA+ uses satellite - derived estimates of land use, rainfall, evaporation, transpiration, interception, water levels of open water bodies, biomass production, crop yield and measured basin outflow to produce a low - cost and reliable water account. These data are supplemented with the outputs of global hydrological models that provide access to explicit data on surface water networks and aquifers and inputs allow calculation of explicit water flows by different land use types, water consumption by the natural landscape and net water withdrawal processes in complex river basins (Karimi et al, 2013).

The share of the individuals and the possibility to Staufer et al (2008) be affected by the changes according to related to the climate change has to be clarified. Namely, the role of every participant has to be identified to face the predicted changes. Because of the complexity of the process (figure 3 ) a thoroughly analysis of stakeholders' and policy makers expectations and requirements with regard to the adaptation of urban water and wastewater management is following. Moreover, the dependencies between risk awareness and an slowly changing weather patterns has to be investigated to be able to start a long-term implementation of mitigation and adaptation measures to encounter the impacts of the climate change. 


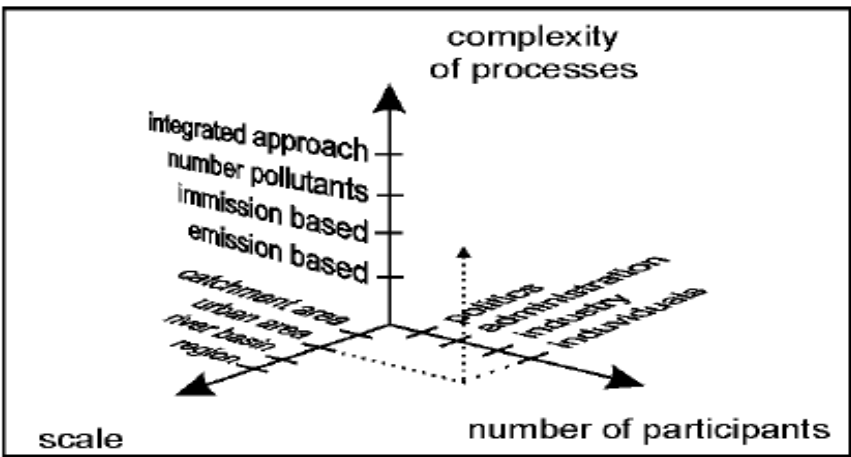

Figure 3 - Space of complexity dealing with water sensitive urban design to adapt the built environment (Staufer et al, 2008)

Table 3 - The basic characteristics of discussed methods of industrial water accounting

\begin{tabular}{|c|c|c|c|}
\hline$n / n$ & Environmental field & Economic field & Social field \\
\hline Water Footprint & $\begin{array}{l}\text { Includes the volume of water used for } \\
\text { production; } \\
\text { Blue, green and gray water; } \\
\text { Simplified pollution: hypothetic water volume } \\
\text { required to dilution of polluted sewage to } \\
\text { values allowable by the local requirements; } \\
\text { Wide range of application; } \\
\text { Excludes watershed properties and its } \\
\text { condition after wastewater discharge. }\end{array}$ & $\begin{array}{l}\text { Includes green water } \\
\text { helpful in irrigation } \\
\text { planning; } \\
\text { Allows simplified analyses } \\
\text { - base to understanding of } \\
\text { role played by water in } \\
\text { production }\end{array}$ & $\begin{array}{l}\text { Excludes possibility to } \\
\text { determine the social } \\
\text { impacts of the } \\
\text { investment. }\end{array}$ \\
\hline $\begin{array}{l}\text { Life Cycle } \\
\text { Assessment }\end{array}$ & $\begin{array}{c}\text { Includes volume and location of water } \\
\text { source; } \\
\text { Includes environmental impacts of the } \\
\text { company; } \\
\text { Wide range of application; } \\
\text { Simplified description of water source and its } \\
\text { renewability; } \\
\text { Excludes effects of water source pollution or } \\
\text { draining on watershed environment. }\end{array}$ & $\begin{array}{l}\text { Allows political and } \\
\text { economic decision making; } \\
\text { Helpful in calculating the } \\
\text { environmental charges. }\end{array}$ & $\begin{array}{l}\text { Includes impacts of } \\
\text { the investment on } \\
\text { social life, life and } \\
\text { health quality of } \\
\text { watershed population. }\end{array}$ \\
\hline $\begin{array}{c}\text { Global Water } \\
\text { Tool }\end{array}$ & $\begin{array}{c}\text { Includes water demand and wastewater } \\
\text { discharge to the environment and their } \\
\text { location; } \\
\text { Analyses based mainly on geo-graphical } \\
\text { data; } \\
\text { Simplified qualitative issues. } \\
\text { Excludes quantitative and qualitative } \\
\text { environmental impacts analyses of the } \\
\text { investment. }\end{array}$ & $\begin{array}{l}\text { Allows only political and } \\
\text { economic analyses related } \\
\text { to range of investments } \\
\text { impacts; } \\
\text { Allows water related risk } \\
\text { management including the } \\
\text { spatial development of } \\
\text { production chain. }\end{array}$ & $\begin{array}{l}\text { Allows only political } \\
\text { and economic } \\
\text { analyses related to } \\
\text { range of investments } \\
\text { impacts; } \\
\text { Allows water related } \\
\text { risk management } \\
\text { including the spatial } \\
\text { development of } \\
\text { production chain. }\end{array}$ \\
\hline $\begin{array}{c}\text { Water } \\
\text { Sustainability } \\
\text { Tool and } \\
\text { Water } \\
\text { Sustainability } \\
\text { Planner }\end{array}$ & $\begin{array}{c}\text { Includes water withdrawn and water sources } \\
\text { assessment, water losses and sewage } \\
\text { discharges; } \\
\text { Allows impacts assessment of the investment } \\
\text { on the water resources of basin. } \\
\text { Excludes qualitative analyses - no } \\
\text { capabilities to quantify the pollutants. }\end{array}$ & $\begin{array}{l}\text { Allows risk management, } \\
\text { strategic management and } \\
\text { strategic development } \\
\text { planning. }\end{array}$ & $\begin{array}{l}\text { Includes presence of } \\
\text { the other users of } \\
\text { water in the } \\
\text { watershed, allows } \\
\text { interaction between } \\
\text { water consumers. }\end{array}$ \\
\hline $\begin{array}{c}\text { Generic } \\
\text { industrial } \\
\text { method } \\
\text { (Schornagel et } \\
\text { al., 2012) }\end{array}$ & $\begin{array}{l}\text { Precisely defined streams of with-drawn } \\
\text { water, its sources and wastewater } \\
\text { discharges as well production losses. } \\
\text { Freely defined quality of analyzed water } \\
\text { streams by optional physical, chemical and } \\
\text { biological parameters. } \\
\text { Simplified environmental analyses } \\
\text { (compliance to local requirements). }\end{array}$ & $\begin{array}{l}\text { Precisely defined streams } \\
\text { of with-drawn water, its } \\
\text { sources and wastewater } \\
\text { discharges as well } \\
\text { production losses. } \\
\text { Freely defined quality of } \\
\text { analyzed water streams by } \\
\text { optional physical, chemical } \\
\text { and biological parameters. } \\
\text { Simplified environmental } \\
\text { analyses (compliance to } \\
\text { local requirements). }\end{array}$ & $\begin{array}{l}\text { Excludes possibility of } \\
\text { social analyses. }\end{array}$ \\
\hline
\end{tabular}

Source: Widomski (2014). 
Analyses of sustainable development on all the three levels are also possible when Global Water Tools, Water Sustainability Tool and Water Sustainability Planner are applied, however these analyses may be shallow and simplified. Despite the fact that qualitative environmental impacts analyses include geo - graphical and demographic data they are markedly simplified or, in some cases, even impossible (in case of Water Sustainability Planner excluding quantifiable wastewater quality). Additionally, the social analyses are limited to determination of the range of water stress zone in the watershed. The limited applicability seems to be characteristic for the another methods presented in this paper, the Water Footprint and industrial methods, e.g. generic by Schornagel, which exclude the direct conducting of the social analyses (see Widomski (2014).

At this point, pointing out the interesting study Qian (2016) or, for example Kern County County in California, USA, which is short of water resources. The county has developed a "water bank" concept that involves storing rainwater during flood seasons below the ground, and then using this groundwater as a resource during dry seasons. The surfaces of roads, ponds, canals, yards, and so forth are all permeable, allowing rainwater to sink into the ground. Within this concept, the groundwater functions just like a bank: Surplus water can be stored in a rainy season and taken out again when needed. The operation of the water bank also follows the rules of a real bank: When users do not overuse their water supply, as indicated by the water consumption standard, the water bank stores any remaining amount of water for their further use. The application of the water bank has obviously lightened the water shortage problem in Kern County, and has raised the groundwater level, as shown in Figure 4 ( see Qian, 2016).

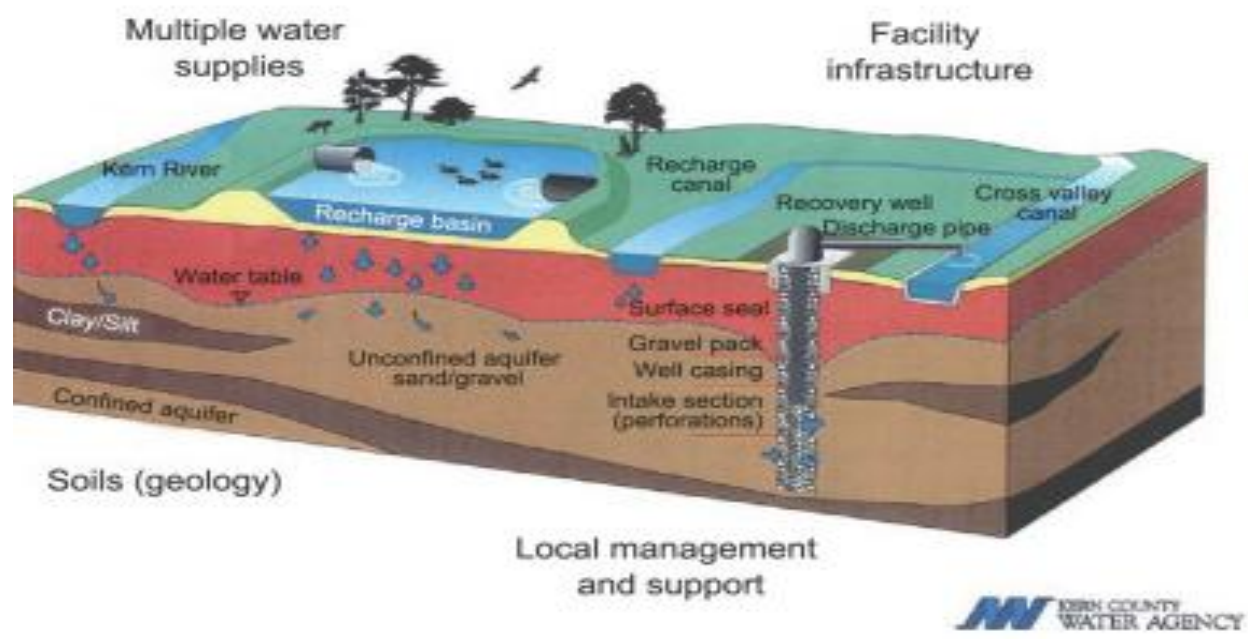

Figure 4 - Diagram of the successful water bank and recovery program at Kern County, California, USA (Qian, 2016)

Therefore, as emphasized Loucks (2000) defining and measuring sustainability is a major challenge. We depend on our water resource systems for our survival and welfare. Yet no one expects them to be restored to, or survive in, their most productive pristine states in the face of increasing development pressures for land in their watersheds and for water in their streams, rivers, lakes, and aquifers. A continuing task of water resource planners and managers is to identify the multiple impacts and tradeoffs resulting from what we who are living today may wish to do for ourselves and our immediate children and what we can only guess our yet-to-be-born descendants may wish us to do, or not do, for them in some distant future. This task must involve professionals from other disciplines in a context much broader than just water management. Once these impacts and tradeoffs are identified, it is then up to the political process to make choices when they are in conflict. All of us need to be a part of this decision - making process ( see Loucks, 2000). 


\section{CONCLUSION}

Climate change and the hydrological variability of water's distribution and occurrence are natural driving forces that, when combined with the pressures from economic growth and major population change, make the sustainable development of our water resources a challenge (www.greenfacts.org ). Sustainable water management according to Russo et al (2014) is a critical component of sustainable development, and accounts for similar issues as sustainability. Russo et al (2014) citing research Mays (2006), Loucks and Gladwell (1999), Alley et al (1999) and Agenda 21(1992) highlights the following definitions. Mays (2006) "sustainable water management are as meeting current water demand for all water users without impairing future supply". "Sustainable water management are should contribute to the objectives of society and maintain ecological, environmental, and hydrologic integrity" (Loucks and Gladwell, 1999). For groundwater management Alley et al (1999) "cites protection of the components in the sustainability triple bottom line: environment, economy, and society". Agenda 21 (1992) ensures that "adequate supplies of water of good quality are maintained for the entire population of the planet, while preserving the hydrological, biological and chemical functions of ecosystems, adapting human activities within the capacity limits of nature and to combat vectors of water - related diseases".

Fact that most decisions in water resources management, at almost all levels, remain principally driven by short-term economic and political considerations that lack the long-term vision needed to implement sustainable development practices. Water management plans should consider the best existing practices and the most advanced scientific breakthroughs. The scientific community has to convey more effectively its recommendations to decisionmakers to enable the latter to develop and maintain multidisciplinary integrated approaches and solutions. Societies should realize that today's water-related challenges are no longer readily solved just by using last century's hydraulic schemes. Increased funding and resources need to be provided for the collection of detailed water data and information (www.greenfacts.org). The Millennium Development Goals (MDGs), agreed in 2000, aim to halve the proportion of people without sustainable access to safe drinking water and basic sanitation between 1990 and 2015. A total of 748 million people still do not have access to an improved drinking water source and existing indicators do not address the safety and reliability of water supplies. To reach the requirements of the right to access to safe drinking water requires real improvements for several billions of people. In July 2010, the General Assembly adopted a resolution, which "recognized the right to safe and clean drinking water and sanitation as a human right that is essential for the full enjoyment of life and all human rights" (A/RES/64/292). The MDG target for sanitation is an even more pressing challenge, with 2.5 billion people currently lacking access to improved sanitation and over one billion still practicing open defecation. At current rates of progress, the sanitation target will be missed by over half a billion people. These global aggregates also mask large disparities between nations and regions, rich and poor, between rural and urban populations, as well as between disadvantaged groups and the general population (www.un.org).

\section{REFERENCES}

1. Vučijak, B., Ćerić, A., Silajdžić, I., Kurtagić, S. M. (2011). Water for Life: Fundamentals of Integrated Water Resources Management. Institut za hidrotehniku građevinskog fakulteta u Sarajevu, pp. 108 -109.

2. Loucks, D., Gladwell, J.(1999). Sustainability Criteria for Water Resource Systems. Cambridge University Press: Cambridge, UK.

3. Xi, X. (2012). Decision Support for Sustainable Water Resources Management in Singapore (Doctoral dissertation, Thesis submitted in partial fulfillment of the requirements for the degree of Bachelor of Engineering. Department of Industrial and Systems Engineering. National University of Singapore.

4. WCED (World Commission on Environment and Development) (1987). Our common future. Oxford University Press. Oxford. 
5. Piao, S., Ciais, P., Huang, Y., Shen, Z., Peng, S., Li, J.,... Fang, J. (2010). The impacts of climate change on water resources and agriculture in China. Nature. Vol. 467, No. 7311 , pp. 43 - 51.

6. Heintz Jr, H. T. (2010). Applying the concept of sustainability to water resources management. Journal of Contemporary Water Research and Education. Vol.127, No.1 (2), pp. $6-10$.

7. World Bank (2007). Coping with Scarce Water in the Middle East and North Africa. Available from: http://web.worldbank.org (25.09 2016).

8. $\mathrm{Li}, \mathrm{H}$. (2009). Water resources management for sustainable development in the Yanqi Basin, Xinjiang, China (Doctoral dissertation, Diss., Nr. 18595). Eidgenössische Technische Hochschule ETH Zürich).

9. Loucks, D.P., et al.(1996). Sustainability of water resource systems: criteria for planning and management, draft manuscript of Joint UNESCO/ASCE monograph.

10. United Nations Educational, Scientific and Cultural Organization (UNESCO) / American Society of Civil Engineers (ASCE)(2006). UNESCO Water e-Newsletter No. 139: Water and industry. Available from: http:// www.webworld.unesco.org (26.09 2016).

11. Chiritescu, V. (2011). Sustainable Rural Development in Romania - Needs and Priority Objectives. Agricultural Economics and Rural Development. Vol. 1, No.1, pp.147 - 160.

12. Rajović,G., Bulatović,J.(2013). Water - economic problems in northeastern Montenegro. Russian Journal of Agricultural and Socio - Economic Sciences. Vol. 4, No 16, pp. 35 45.

13. Rajović,G., Bulatović,J.(2014). Water geographic values Northeastern Montenegro. Larhyss Journal. Vol. 17, No.17, pp. 115 - 133.

14. Rajović,G., Bulatović,J.(2016). Possibility of use of water in the economy of Montenegro. Larhyss Journal. Vol. 25, pp. 7 - 30.

15. Rajović,G., Bulatović,J.(2016). Rural Roads - Issues and Development: Overview. UCT Journal of Management and Accounting Studies, Vol. 4, No. 4, pp. 76 - 85.

16. United Nations (1992). Agenda 21, In Proceedings of the United Nations Conference on Environment \& Development. Rio de Janero, Brazil, 3 - 14 June.

17. FAO (2011). Coping with water scarcity: An action framework for agriculture and food security. Rome (FAO Water Reports 38).

18. FAO (2013). World Water Resources by Country. Available from: http://www.fao.org (02.10 2016).

19. The Water Institute; Gillings School of Global Public Health; University of North Carolina (2014). Building integrated approaches into the Sustainable Development Goals. A declaration from the Nexus 2014: Water, Food, Climate and Energy Conference in the name of the Co-directors held at the University of North Carolina at Chapel Hill, March 5 - 8, 2014, Submitted to the UN Secretary General on March 27. Available from: http://nexusconference.web.unc.edu (27.09 2016).

20. IWMI (International Water Management Institute)(2014). Wetlands and people. Colombo, Sri Lanka.

21. United Nations Department of Economic and Social Affairs (UNDESA)(2015). Water and sustainable development. International Decade for Action "Water for Life" 2005 - 2015. Available from: http://www.un.org (29.09 2016).

22. United Nations Millennium Development Goals (MDGs)(2015). Rights to Water and Sanitation. Available from: http://www.un.org (30.09 2016).

23. Farm Zero (2016). Water Resources of Earth. Available from: http://www.farm-zero.com (01.10 2016).

24. Love, J., Luchsinger, V. (2014). Sustainability and water resources. Journal of Sustainability and Green Business. Vol. 2, pp. 1- 12.

25. Flint, R. W. (2010). The sustainable development of water resources. Journal of Contemporary Water Research and Education. Vol.127, No.1, pp. 6.

26. Vorosmarty, C. J., Green, P., Salisbury,J., Lammers, B.R.(2000). Global water resources: vulnerability from climate change and population growth. Science. Vol. 289, pp. 284 - 287. 
27. Ryan, J.C. (1997). Stuff - The Secret Lives of Everyday Things. Seattle, WA: Northwest Environmental Watch.

28. Omer, A. M. (2010). Water resources management and sustainable development in Sudan. International Journal of Water Resources and Environmental Engineering. Vol. 2, No. 2, pp. 190 - 207.

29. Karimi, P., Bastiaanssen, W.G.M., Molden, D. (2013). Water accounting plus (WA+) - a water accounting procedure for complex river basins based on satellite measurements. Hydrology and Earth System Sciences. Vol. 17, No. 7, pp. 2459 - 24.

30. Staufer, P., Siekmann, M., Roder, S., Pinnekamp, J. (2008). Sustainable development of regional water resources management confronting climate trends and extreme weather, pp. 1-10. In Proceedings on CD, 11th Int. Conf. on Urban Drainage (ICUD). Edinburgh, Scotland, UK.

31. Widomski, M. (2014). Selected methods of water resources accounting in the aspect of sustainable development. PROBLEMY EKOROZWOJU - PROBLEMS OF SUSTAINABLE DEVELOPMENT. Vol. 9, No. 1, pp. 141 - 150.

32. Schornagel, J., Niele, F., Worrell, E., Böggemann, M. (2012). Water accounting for (agro) industrial operations and its application to energy pathways. Resources, Conservation and Recycling. Vol. 61, pp. 1 - 15.

33. Qian, Y.(2016). Sustainable Management of Water Resources. Engineering. Vol. 2, No. 1 , pp. $23-25$.

34. Loucks, D. P.(2000). Sustainable water resources management. Water international. Vol. 25, No. 1, pp. 3 - 10.

35. GreenFacts - Facts on Health and the Environment (2006). How could water resources be developed sustainably? Available from: http://www.greenfacts.org (28.09 2016).

36. Russo, T., Alfredo, K., Fisher, J. (2014). Sustainable Water Management in Urban. Agricultural and Natural Systems. Water. Vol. 6, No.12, pp. 3934 - 3956.

37. Mays, L.(2006). Water Resources Sustainability. McGraw - Hill Professional: New York. NY, USA.

38. Alley, W., Reilly, T., Franke, O.(1999). Sustainability of Ground - Water Resources. US Department of the Interior. US Geological Survey: Denver, CO, USA. 